\title{
Incoincidências de autoras: Fragmentos de um discurso não só amoroso na literatura da Guerra Colonial
}

Non-coincidences of women authors. Fragments of a not-only-about-love discourse in the literature of the Colonial War

Incoincidences d'auteurs : fragments d'un discours entre autres amoureux dans la littérature de la Guerre Coloniale

Roberto Vecchi

\section{OpenEdition}

Journals

Edição electrónica

URL: http://journals.openedition.org/rccs/1083

DOI: $10.4000 /$ rccs. 1083

ISSN: 2182-7435

\section{Editora}

Centro de Estudos Sociais da Universidade de Coimbra

Edição impressa

Data de publição: 1 Junho 2004

Paginação: 85-100

ISSN: 0254-1106

Refêrencia eletrónica

Roberto Vecchi, «Incoincidências de autoras: Fragmentos de um discurso não só amoroso na literatura da Guerra Colonial », Revista Crítica de Ciências Sociais [Online], 68 | 2004, colocado online no dia 01 outubro 2012, criado a 01 maio 2019. URL : http://journals.openedition.org/rccs/1083 ; DOI : $10.4000 /$ rccs. 1083 


\section{Incoincidências de autoras: Fragmentos de um discurso não só amoroso na literatura da Guerra Colonial}

Se a guerra é por excelência o território do androcêntrico, a experiência traumática da guerra e a sua representação pelo olhar feminino enxertar-se-ão numa margem periférica, numa orla de deslocação da própria experiência traumática. Deste ponto de vista, o feminino torna-se por excelência um "olhar testemunhal", sendo a possibilidade sobrevivente, residual, da impossibilidade do testemunho integral diante do evento traumático. Uma deslocação esta que evidencia a não coincidência entre experiência e imagem, própria do testemunho, em que lógos e memória femininos se tornam portadores contundentes de um outro lógos, duma contra-memória. Os romances de Wanda Ramos e Lídia Jorge são recolocados também na problemática trágica da aporia testemunhal, mostrando como uma reflexão crítica sobre o trágico moderno pode proporcionar uma perspectiva mais compreensiva de uma literatura problemática - pelo seu corpo a corpo com a história - como a da Guerra Colonial.

Não testemunhará isto quem morreu.

Antígona, 515

\section{Uma dupla impossibilidade}

Não são necessárias muitas reflexões para perceber de imediato que o plano onde vão escorrer as considerações que se seguem é inexoravelmente inclinado e até escorregadio. De facto, como é possível pensar num objecto em si já tão opaco como a assim chamada "literatura da Guerra Colonial" que apresenta problemas críticos ainda não solucionados acrescentando um elemento a mais de perturbação, como a sua reconfiguração dentro duma vertente feminina? Poderá existir uma literatura feminina da Guerra Colonial se não temos certeza de que exista autonomamente (cf. Laranjeira, 1991: 12) uma literatura da Guerra Colonial? A pergunta é obviamente retórica, porque, se não implicasse uma resposta afirmativa, não mereceria a pena aprofundar este discurso. Mas é escusado considerar que há, nessa impossibilidade pelo menos dupla, um emaranhado bastante complicado por destrinçar. 
A guerra como experiência do trauma perturba a ordem da representação, ainda que, por paradoxo, a codificação da sua memória necessariamente transite através de um acto de autor, dependendo portanto das virtualidades implicadas pelo domínio do literário. Mas as mulheres, para afirmar o seu ponto de vista, têm que travar uma outra guerra, uma guerra mais subtil e menos perceptível, entranhada nas vísceras ocultas e profundas da história humana a que chamamos "do homem", que é aquele lugar de guerra (Magli, 1985: 15), a linguagem, onde se colocam as relações polémicas e os jogos de força dos sentidos ocultos e patentes, em que convencionalmente o sujeito feminino se inscreve no marco da derrota, como ausência ou falha da linguagem, pura vivência sem pensamento ou palavra.

Um ícone nesta perspectiva emblemático, pelo vazio que o demarca, é representado pela narratária feminina de Os Cus de Judas de Lobo Antunes, figura complexa e decisiva, cuja presença muda e transparente torna, no entanto, viável o monólogo-testemunho do narrador. Pela aporia própria do mecanismo testemunhal que de facto não poderia realizar-se sem um processo de re-subjectivização da experiência vivida e incomunicável do trauma - como mostra o paradigma de Auschwitz definido por Giorgio Agamben (Agamben, 1998) -, a mulher com o corpo quase invisível, reduzido a poucos detalhes descritivos e que sobretudo nunca toma a palavra, desempenha uma função básica na realização do acto de autor que é o romance, tornando o testemunho não só possível mas até viável. Mas será que é só pela sua posição deslocada, pela sua incoincidência entre experiência e imagem do trauma bélico que, como sabemos, pelo menos em termos de guerra moderna e convencional, é um domínio androcêntrico, que o sujeito feminino, mantendo-se na obscuridade da margem, possibilita a representação "dramática" da experiência, simplesmente fornecendo um tu a um eu vitimado pelo evento traumático que assim pode assumir a máscara ainda toda masculina de um ele, de uma terceira pessoa? Ou não passaria isso de mais uma ratificação da ordem sexista, quando, na verdade, a escrita feminina da Guerra Colonial deveria tomar um rumo drasticamente oposto e opositivo?

No entanto, o problema existe: como é que uma figura silenciosa e silenciada, a mulher perante a guerra, pode contribuir para representar um tema, silencioso e silenciado, como a representação da Guerra Colonial? Aqui, é preciso frisar que até as dimensões do próprio corpo textual feminino da Guerra Colonial não se prestam a nenhuma imediata canonização. Deverão os textos ser incluídos em função da maior ou menor distância do evento que representam? A Guerra Colonial deverá ser entendida stricto sensu ou, pelo contrário, na acepção ampla que por exemplo lhe dá João de Melo, ao 
interpretá-la como uma teoria sem solução de continuidade a partir do começo da expansão, portanto fazendo com que ela adira à história da expansão tout court e, portanto, a iconografia historicamente sedimentada da expansão, a viagem, o cais, o tempo plúmbeo das esperas frequentemente desiludidas (Ribeiro, 2002: 212), deverá ou não ser contemplada? Textos-chave que simbolizam todos os tipos de oposição feminina à cultura sexista e patriarcal como as Novas cartas portuguesas poderão ser incluídos enquanto metáfora de todas as formas de opressão (Magalhães, 1995: 22)?

A cartografia da literatura feminina sobre a Guerra Colonial poderia até reduzir-se aos traços esverdeados de um hotel da costa do Índico, a dois rios de Angola que marcam as temporalidades diferenciadas de uma vivência, a um cais de despedida com um mar trágico ao fundo, ou, mas já outro é o contexto, um remoto campo militar timorense. A conjugar esses lugares fragmentados seriam outros fragmentos de um tema, a guerra, que não se deixam captar a não ser pela margem, pelo externo, por uma proximidade emotiva que é distância física e lógica do contexto bélico. Isso sem negar que há traços conjuntivos mais profundos nessa perspectiva sexuada da guerra que não decorre só do ângulo de visão sociológico, o papel desempenhado pelas autoras, de "mulher de alferes miliciano", distantes portanto dos factos testemunháveis, como por exemplo no apego à memória como palimpsesto da escrita, comum a essa literatura como um todo, mas que aqui assume conotações próprias.

A pergunta que pode surgir é se essa deslocação proporciona um sentido de conhecimento mais amplo do que um ponto de vista individual de uma experiência como a do trauma colectivo que não se deixa apreender, fugindo às tentativas de representação. De facto, o que não faltam são exemplos, a guerra com os seus excessos - traumas, extremos - resiste, não se entrega à representação. Aliás, é um excesso que transpõe os limites estéticos funcionais da arte. Foi justamente perante essa dimensão do ilimitado, própria da modernidade, que se criou uma categoria inclusiva do que não cabia nas molduras do belo, a do sublime. A relação aliás entre trauma e sublime é evidente: o trauma é uma ocasião de sublime, são os pontos extremos em contraste que não admitem ou até desfiguram qualquer mediação (La Capra, 2001: 190).

Mas será possível combinar o limite que a mulher habita perante o evento traumático da guerra (colonial) com o ilimitado da experiência traumática "excessiva" (Friedlander, 1992: 19) que dá lugar ao sublime? Essa incoincidência, contrariamente a quem pensa que só a autoridade da experiência directa da guerra legitima a sua escrita, na verdade, confere à perspectiva feminina uma imensa vantagem: efectivamente, escrever o trauma, pode- 
ríamos dizer, como metáfora implica um distanciamento, o da escrita, que tornaria a literatura feminina da Guerra Colonial um lugar paradoxalmente privilegiado da sua possível representação (La Capra, 2001: 186). Mas a condição testemunhal da autora embate na densidade peculiar do objecto, da experiência, traumática, que não se deixa representar, na condição constitutiva de irrepresentabilidade implicada pelo sublime e sedimentada desde a sua origem, que pertence como sabemos ao campo do medo, medo da perda do eu, da morte, do inconcebível (Seligmann-Silva, 1998-99: 115).

É tentando conjugar esses temas em torno de uma diferença sexual que consegue articular formas do sublime que pensei que talvez não fosse errado, embora ainda não se tenha tentado, encontrar um elo compreensivo da literatura feminina da Guerra Colonial justamente nas suas dobras mais problemáticas, na margem mais obscura e silenciosa que perturba a sua própria instituição como objecto que foge a qualquer tentativa de apreensão. A sua precariedade ou o limite leva a meu ver a pensar essa literatura a partir da sua própria aporia, da sua dupla impossibilidade.

Fora de saídas viáveis, das mediações que se podem alcançar através de um percurso crítico, de um método, o problema da representação do trauma encontra, na modernidade, um campo paradoxal que deixa aberto os extremos inconciliáveis dos conflitos, sem os fechar em impossíveis sínteses, um campo onde, como diz Sergio Givone, há "um pensamento que uma vez pensado se entrega à sua impensabilidade" (Givone, 1996: XIII). Trata-se do campo opaco e mudo onde se tenta representar o que em si é irrepresentável, mas de que ao mesmo tempo é necessário tentar, e possivelmente encontrar, a representação: o mal, a morte, o trauma, a dor. Ou o trauma da guerra. E não é por acaso que o sublime fornece a esse campo um importante paradigma. Esse campo é o campo do trágico. O trágico moderno, mais exactamente, para distingui-lo do género aristotelicamente canonizado da tragédia ou do trágico antigo com que ao mesmo tempo mantém relações complexas, residuais, sendo uma sua actualização - ou melhor uma sua "tradução" - fora do contexto mitológico originário.

A dupla impossibilidade da literatura feminina da Guerra Colonial talvez possa encontrar numa reflexão sobre o seu núcleo trágico um território onde o pensamento do trauma possa chegar a uma representação própria e a representação da experiência traumática possa, assim, ser pensada, para expressar a aporia trágica a partir de uma figura - digamos assim - recompositiva do contraste como a do quiasmo. Sobretudo a transcrição da aporia no campo do trágico moderno proporciona um arsenal crítico considerável, de índole transdisciplinar, filosófico e estético, que transforma o limite da dupla impossibilidade, de pensar e representar o conflito, num limiar que 
escancara um campo onde reconjugar as questões em jogo. Aliás, talvez seja possível, a partir do recorte da problematização da literatura feminina da Guerra Colonial dentro das porosas molduras do trágico moderno (que se apoiam no repositório crítico de uma imensa tradição aliás conflituosa) esboçar bases conceptuais de problematização mais ampla, que investem - elipticamente, nestas considerações - a literatura da Guerra Colonial ou ainda, de modo mais geral, da representação da guerra como um todo.

\section{2. (Quase) lutos, cicatrizes, epitáfios}

A primeira questão, digamos assim, trágica com que deparamos - assumindo aqui uma ideia moderna de trágico como conflito inconciliável (Goethe) é certamente a mais aporética e fundacional da literatura da guerra, ou seja, a da testemunha. Um testemunho que se articule a partir de uma não coincidência entre a testemunha integral, que é titular da experiência traumática mas não pode expressá-la, e o acto que por definição jurídica chamamos de autor, isto é, de quem torna válido um acto que em si não o poderia ser. O testemunho, portanto, na reconstrução já bastante conhecida de Giorgio Agamben, surge sempre como acto de um autor (de uma autora, no caso) dentro de um conflito, de uma dualidade essencial, em que uma insuficiência e uma incapacidade se integram e validam, tornando assim o testemunho um resto, o que resta entre as suas duas lacunas constitutivas, entre os mortos e os sobreviventes, entre indizível e dizível, entre o titular mudo da experiência incomunicável e o autor que fala da experiência dum Outro (Agamben, 1998: 138-140 e 152-153). ${ }^{1}$

Nesse sentido, a literatura feminina da guerra coloca-se plenamente enquanto acto de autoras que preenchem a lacuna linguística das testemunhas integrais e o distanciamento que se evidencia do cenário bélico é o pressuposto que possibilita o acto testemunhal doutro modo impossível ou, pelo menos, problemático. Por isso, nessa literatura dá-se testemunho de eventos indizíveis, como os massacres (por exemplo o de Wiriamu) ou os horrores da guerra documentados fotograficamente e que todos vimos e gravámos na memória, mas que em si não poderiam testemunhar, dando portanto voz às vítimas silenciosas, isto é, às testemunhas integrais, que doutro modo permaneceriam sem representação. $\mathrm{Na}$ era da testemunha, em que é árdua - até trágica - a relação entre testemunho e história, a literatura oferece actos de autores/as essenciais para uma efectiva compreensão histórica.

\footnotetext{
1 Sobre a problemática do testemunho como resto na literatura da Guerra Colonial, permito-me remeter para Vecchi, 2001a:317-327, e Vecchi, 2001b:389-399. Para uma crítica da perspectiva de qualquer modo inovadora de Agamben, onde em relação ao nome de Auschwitz "a toponímia se torna antonomásia”, veja-se Mesnard e Kahan, 2001: 55.
} 
Há uma frase-chave que a meu ver o famoso jornalista da "Coluna involuntária" de A Costa dos Murmúrios entrega a Eva Lopo que foi Evita: "Devemos enterrar os mortos e cuidar dos vivos" (Jorge, 1988: 171) e que corporiza uma tópica fundadora da literatura da guerra. ${ }^{2}$ Nessa relação entre vivos e mortos dá-se um tema fundamental da literatura da guerra que também remete para a problematização (trágica) do resto. A melancolia das representações já foi vista como um traço estruturador do corpus literário, mas é no conflito pós-freudiano entre luto e melancolia que se desvenda uma matriz importante a ser repensada, que confere aos autores (às autoras) o papel de "guardadores de túmulos"3 de uma literatura que se propõe patentemente um fim terapêutico, fazer o trabalho do luto, reactivando, aliás, assim o importante elo etimológico que une túmulo e signo ${ }^{4}$. De facto, a relação entre melancolia e luto é hoje recolocada nos seguintes termos trágicos, de reabilitação da melancolia sobre o luto: há sempre um resto que não pode ser integrado na elaboração do luto e no melancólico a fidelidade até ao extremo é a que é dirigida para esse resto, como se o luto fosse uma traição, uma segunda morte. Como foi notado, isso torna-se possível por um erro "teorético" do melancólico que coloca a resistência num objecto realmente existente mas perdido: o erro é confundir a perda com a falta, de acordo com o qual um objecto que nunca se teve, mas que se considera como perdido, pode ser assim possuído (Zizek, 2002: 39-40). ${ }^{5}$ Nessa reconstrução, o que vale a pena sublinhar - além de mais uma conceptualização que centraliza a problemática residual, do resto, não só pela vertente testemunhal, mas também pela relativa à elaboração das perdas traumáticas da guerra - é a relação de proximidade conflituosa entre melancolia e luto, onde a primeira, ambivalente e complexa, teria um paradoxal disfarce enlutado, um "quase" luto (Agamben, 1993: 26), de modo que um corte crítico fora do campo das tensões trágicas se tornaria aporético.

A melancolia, portanto, também exigiria, por sua vez, uma incoincidência, uma deslocação, como ocorre, por seu lado, com a aporia testemunhal, no deslize, no shifting, entre falta e perda que recoloca a distância do evento traumático como fundamental para articular o seu trabalho, a sua elaboração. De algum modo, se quiséssemos iconizar o núcleo trágico da questão, poderíamos encontrar um correlativo adequado num resto específico do

\footnotetext{
${ }^{2}$ Cf. e.g. autores como Fernando Assis Pacheco ou José Bação Leal.

${ }^{3}$ De acordo com a leitura criptofórica de Abraham e Torok sobre a incorporação do trauma como cripta (cf. Abraham e Törok, 1987: 247).

${ }^{4}$ Ambos derivam do grego sêma, que indica a pedra tumular.

${ }^{5}$ Sobre a importância da problematização entre falta e perda para a distinção entre traumas trans-históricos e históricos, cf. La Capra, 2001: 43-85.
} 
passado, na relíquia e no complexo por ela implicado que pressupõe um processo pelo menos dual: a relíquia, desde os mitos mais antigos, simboliza que o passado, o morto, não regressa no presente, mas ao mesmo tempo cria também a ilusória reunião do passado com o presente, dos mortos com os vivos. A relíquia une e separa o presente do passado. Como a recordação que é por excelência relíquia secularizada, como na célebre definição de Benjamin.

Essas generalidades testemunhais e metapsicológicas servem para recolocar na literatura feminina da Guerra Colonial uma questão que lhe é crucial e até fundamentadora, a questão da memória. De facto, se há um traço que une os textos literários da Guerra Colonial, e particularmente os femininos, este é, como notou Maria Irene Ramalho, num ensaio sobre $A$ Costa dos Murmúrios, seminal de muitos outros estudos sucessivos, o uso duma memória disjuntiva, conflituosa, em "um aproveitamento aparentemente paradoxal do modo autobiográfico como estratégia de distanciação" (Santos, 1989: 64). Aliás, sobre a questão da memória podemos contar com excelentes ensaios como os de Paulo de Medeiros $^{6}$ que não vou aqui resumir. Quanto à memória "trágica" presente na literatura feminina da Guerra Colonial (refiro-me, em particular, aos romances de Wanda Ramos e de Lídia Jorge), gostaria de frisar que o "murmúrio", a "bolha" da memória da experiência bélica se sexualiza (cf. Magalhães, 1997: 294) de modo peculiar nestes textos. O primeiro aspecto, que a meu ver se torna evidente, é o de uma memória de cicatrizes. Entendo aqui cicatriz num duplo sentido, próprio de ferida física, mas também figurado, ou seja, de marco de ofensa, rasto de uma experiência destrutiva, figura que mantém viva uma tensão, um conflito entre lembrar e esquecer. De facto, se em português o verbo esquecer deriva do latim cadere (Weinrich, 1999: 9) que aproxima o seu sentido ao de ruína (deverbal de ruo, queda, desabamento) ou seja, o que sobrevive à destruição ainda que submerso no esquecimento, também a palavra cicatriz pode considerar-se o deverbal do mesmo verbo latino, o que não é desprovido de consequências relevantes se a cicatriz for interpretada, no corpo, à luz da rica semiologia das ruínas. A arte da memória sobrepõe-se, assim, à prática de leitura de cicatrizes, como mostra eloquentemente, por exemplo, Georges Perec quando atesta a importância de uma cicatriz no seu lábio superior que desencadeia as suas memórias autobiográficas (Seligmann-Silva, 1999: 46).

\footnotetext{
6 Sobre a relação memória-história em $A$ Costa dos Murmúrios, cf. em particular a contribuição de Paulo de Medeiros (1999: 61-77) e também a sua instigante leitura contrastiva do uso da memória no romance da guerra de Lobo Antunes e Lídia Jorge em Medeiros, 2000: 47-76.
} 
A rede de cicatrizes literárias é plural: temos as superexpostas como, em A Costa dos Murmúrios, a cicatriz resplandecente do capitão Forza Leal, o símbolo violáceo e exibido da ideologia bélica colonial e dos seus retóricos, mas ainda sedutores e fatais, mitos heróicos que se lhe associam ou se procuram barbaramente em seus turvos reflexos, ou até as irónicas simultaneidades trágicas que sempre pela figura da cicatriz surgem e organizam o fluir da memória paradoxal e inconsequente, como no caso da "vergonhosa" cicatriz (para todo o sistema) esfinctérica da mulher do tenente Zurique. No entanto, uma ilumina o sentido - trágico - da outra. Mas, ao lado dessas cicatrizes próprias, ainda que carregadas de sentidos íntimos e profundos do acto crítico, há inúmeras outras cicatrizes que tecem uma rede de feridas bem ou mal cicatrizadas mas que se reabrem facilmente quando encontram o acesso às fontes afectivas inconscientes. Por todas as narrativas estão disseminadas essas cicatrizes, cacos cortantes da infância do contexto colonial, os flashes de fel e de mágoa do Leste de Angola (Percursos), atrocidades lúdicas, mitos de uma honra anacrónica, massacres gratuitos que não admitem testemunha, mas que o narcisismo delirante capta e arquiva na superfície sensível da película fotográfica ( $A$ Costa dos Murmúrios). A memória de cicatrizes que se tece é uma memória de vácuos, intermitências, restos, mas que reconfigura e borda uma imagem do passado que se subtrai ao esquecimento ou luta contra ele. O esquecimento é um dos fios essenciais dessa nova textura, como também exibem os textos.

A inscrição da ferida no corpo, a memória de cicatrizes, não só temporaliza, data a experiência (e, como a relíquia, une e separa daquele passado), mas, ao mesmo tempo, confere às cicatrizes metafóricas uma espessura física, traduzindo o trauma numa memória inapagável que se pode conservar. Assim, converte-se a cicatriz (portanto a dor) em ícone, em tatuagem que outros podem decifrar pelo texto, pela textura nova que as conjugações impensadas de cicatrizes formam (no peito de Forza, no esfíncter da mulher do tenente), proporcionando um novo modo de re-escrever e, portanto, de ler a história. O corpo conserva a dor, mas conserva também a resistência à dor.

A verdade (aletheia) depreende-se dum corpo a corpo com o esquecimento, como um movimento que de qualquer modo não pode prescindir, apesar da resistência, da dimensão do esquecimento. Lete e Mnemosyne, o rio e a fonte, o Luachimo e o Luena da experiência surgem como conflito que não se recompõe, não se resolve. E é na diferença sexual, onde o corpo é registo de repressão e resistência, que se pode tecer a memória trágica de cicatrizes. E é por esse viés metonímico mais do que metafórico do corpo 
que pode dar-se a passagem alegórica do individual para o colectivo, da crise pessoal para a da nação que é experiência da crise mais do que a metáfora dela.

Há também um segundo aspecto ainda "trágico" por sublinhar, sempre em relação à memória (por sua vez trágica) da guerra. Um traço bem perceptível que marca as prosas da Guerra Colonial, é o da voz das contranarrativas. ${ }^{7}$ É verdade que a memoria vocis que assim se configura assume feições bem características que afectam a própria textura discursiva, tanto em A Costa dos Murmúrios como em Percursos. O problema da voz em função da escrita feminina desvenda uma questão muito interessante: houve de facto uma ruptura no âmbito da cultura ocidental do que se definiu com Aristóteles como a "voz significante" (phonè semantikè) por excelência fundadora do discurso humano. A desvocalização platónica da voz significante abre uma fenda entre voz e lógica, entre dizer e dito, de modo que Adriana Cavarero, reconstruindo uma tradição e dialogando com a reflexão de Cixous e Kristeva, indica como o território da voz (e do corpo) é prevalentemente feminino, enquanto o logos se centraliza em torno do domínio masculino (Cavarero, 2003: 110-114, 154-161). A peculiaridade da voz que se articula a partir das escritas femininas da Guerra Colonial necessita da configuração de uma outra lógica discursiva que possa preencher as lacunas do antigo pacto da "voz significante".

Se repararmos bem nas estruturas dos romances, aperceber-nos-emos de como o seu funcionamento "out of joint", fora de padrão, aparentemente a-lógico ou anti-lógico, é talvez motivado pela cisão originária entre voz e lógica. Por isso, em Percursos temos uma voz que se articula a partir de uma montagem caótica e não linear de reminiscências que tecem uma outra lógica discursiva. De forma semelhante, o estranhamento que provoca o aparente caos mnésico da segunda parte de $A$ Costa dos Murmúrios contrasta com a simetria falsa da primeira, de "Os gafanhotos" de autoria masculina, até a anular. E, justamente, em $A$ Costa dos Murmúrios ressalta admiravelmente a violação dos códigos que organizam o eu, a lógica do discurso pelo fluxo das vozes em que há gritos, choros, risos, sensações que proporcionam na escrita o evento da sua desagregação, da sua desorganização. E qual é a história que pode surgir dos restos dessas memórias vocais e individuais, se uma história puder efectivamente surgir? É uma história que explora dimensões implícitas e singulares, o que normalmente fica fora da história: os sentimentos, os desejos, a consciência, os instintos.

\footnotetext{
7 Relativamente a essa diferença entre o primeiro livro "Os Gafanhotos" e o segundo livro de Eva em $A$ Costa dos Murmúrios, Helena Kaufman foi chamando a atenção para a "alternância da voz narrativa" (Kaufman, 1992: 42).
} 
Um outro ícone que talvez contribua para entender melhor o sentido só aparentemente caótico e absurdo dessas memórias despedaçadas é o do epitáfio, pela constelação de elementos simbólicos que coagula. De facto, o epitáfio tem origem discursiva (epitàfios lògos), como oração funerária para honrar os caídos em batalha que depois se transforma em inscrição tumular (etimologicamente), mas também, como assinala Johanna Dahm, em monumento que não se ergue no túmulo, mas, frequentemente, nas suas cercanias (Dahm, 2002: 166). Ou seja, o epitáfio simboliza, enquanto obra, a memória na ausência do cadáver, desempenhando, no entanto, uma função primária comemorativa, que se justapõe também a uma função secundária e menos evidente de tipo moral-didascálico: o monumento institui-se exibindo a distância dos restos que o justificam, mas trata-se de uma distância que articula o que os restos em si não poderiam recompor, ou seja, um certo sentido, ainda que precário, da história para as não testemunhas. Epitáfios dispersos da crise que só remetem para fragmentos do que se escoou, do passado. Na literatura feminina da Guerra Colonial, bem mais do que uma história há de facto uma genealogia que procura não um fim, mas os restos, os escombros que se mantiveram na dispersão do tempo, circunstância que, de acordo com a genealogia foucaultiana, faz da história uma contra-memória. Não é por acaso que Foucault sublinha a relação que se institui entre corpo e história, remetendo para outra visão trágica e ruinosa do tempo: "O corpo: superfície de inscrição dos eventos [...] volume em perpétua erosão. A genealogia, como análise da proveniência, è, portanto, a articulação do corpo e da história: deve mostrar o corpo todo marcado pela história, e a história que devasta o corpo". (Foucault, 1977: 37)

\section{Enterrar os mortos: as Antígonas trágico-modernas da Guerra Colonial} Mas reunindo todos os fios trágicos, residuais, das autoras da Guerra Colonial, como interpretar a dimensão trágica que (res)surge - como pensamento e representação - na modernidade e qual a sua relação com os moldes da tragédia clássica? E de que modo o reconhecimento dessa dimensão trágica nos ajuda a elaborar o luto, a encontrar para os mortos o seu lugar de sepultura, enfim, a pensar num sentido histórico que torne citáveis os sofrimentos inconclusos dos mortos no presente, no mundo dos vivos? E além desta vertente benjaminiana, como é que o trágico recoloca a literatura da Guerra Colonial a partir da sua voz feminina?

É preciso desde logo frisar que a tragédia clássica é um género de retaguarda em relação ao teatro da guerra, o que de algum modo contribui para pautar as relações entre tragédia e épica. A tragédia assume motivos da épica e tradu-los em objecto de meditação ético-política. Há uma incoin- 
cidência originária, portanto, entre trágico e épico (que Aristóteles aliás glosa na Poética, derivando a épica da tragédia e não vice-versa [Aristotele, 2000: 123]). É por isso que é imediato associar às profundezas do trágico a literatura feminina da Guerra Colonial e a sua deslocação em relação aos eventos traumáticos percebidos à distância, como reflexo deformado, no entanto fundador, de um pleno acto testemunhal, de um acto de autora, porque eles são recolocados como motivos de uma reflexão que recostura um sentido outro da história conectando os fragmentos dispersos do passado, num gesto redentor do sentido histórico. Um gesto carregado de um conteúdo ético-político, ainda que não coincidente com a história sobre a qual se debruça.

O fragmentarismo, aliás, revela a dimensão plenamente moderna do trágico que está em jogo. Um trágico “abastardado” em relação à tragédia clássica: não irei aqui aprofundar uma questão complexa - e até "trágica" em si - como a de detectar as relações entre trágico antigo e trágico moderno sobre as quais se confronta uma tradição de pensamento amplíssima e contrastante, mas basta pensar que, numa das suas leituras clássicas, Kierkegaard ("O reflexo do trágico antigo no trágico moderno") aponta para o traço residual que o funda, observando que, no processo, o trágico permanece o trágico mas que é preciso sondar o que "enriqueceu" (portanto transformou) o conceito (Kierkegaard, 1988: 22). Ou seja, há como uma deflagração dos estilhaços dos motivos da tragédia que se traduzem no trágico moderno e que se realinham na textura narrativa - por um rebaixamento e uma oscilação, poderíamos dizer, que chega a roçar até o kitsch, próprios do polimorfismo da forma romance - conservando, no entanto, os restos da memória trágica.

Os cacos trágicos (e metatrágicos) disseminam-se pelas prosas em questão: pense-se na estrutura "teatral" da escrita de Percursos ou em rasgos críticos do tipo "Era preciso não dizer nada ao tenente, porque de novo aquela era uma coincidência trágica. E o que é a tragédia senão uma deslumbrante coincidência?" (Jorge, 1988: 188) ou "despudoradamente fabricar inúmeras escritas, catarse mastigada, a fala por fim logrando recuperar-se” (Ramos, 1981: 80).

No trágico moderno, se quisermos esboçar uma conceptualização simplificadora, ocorre uma substituição peculiar que nos reconduz a um dos pais fundadores do romantismo italiano, Alessandro Manzoni. Ele dedica-lhe uma atenção especial, num texto teórico ${ }^{8}$ sobre a tragédia em que

\footnotetext{
${ }^{8}$ Lettre à M.r Chanvet sur l'unité de temps et de lieu dans la tragédie (1823), que decorreu da experiência de composição duma tragédia "moderna" como Il conte di Carmagnola (1820). Cf. Manzoni, 1999.
} 
explica uma intuição evidente, mas esclarecedora, que redefine as relações entre tragédia e trágico. Para Manzoni, o trágico moderno deve reelaborar o lado obscuro da história, mas nisso ele capta também uma analogia essencial: há de facto uma simetria directa entre o mito da tragédia antiga e a história da tragédia moderna; ou seja, no trágico moderno, a realidade histórica vai substituindo o mito, o que implica - como foi observado - que na tragédia clássica é o mito que representa o seu material da realidade, mas também que a função do mito da tragédia é exercida no trágico moderno pela realidade histórica (Maj, 2001: 1269).

A substituição do mito pela história dentro da memória escrita da guerra desenha o perfil do trágico nas obras a partir inclusive de marcos que remetem directamente para o mito (épico) como Helena de Tróia em A Costa dos Murmúrios - "Mas Helena de Tróia era a abstracção de quê? [...] Os gregos, pais dos nossos mitos, não inventaram essa fragilidade nem a malevolência dessa fragilidade (Jorge, 1988: 90) - ou imagens onde a história se enxerta na carne viva do trágico - "despertar de terra libertando-se/do marasmo de musgo da opressão/extensa tragédia tecida/ancestralmente com vagares de sangue" (Ramos, 1981: 67).

Ora, nas dobras ocultas da história, o mito continua a pulsar, ainda que residual. E como seria possível não se deixar sugestionar pelo mito trágico daquela que é considerada (Hegel) o paradigma da tragédia por excelência que é a Antígona de Sófocles, sobretudo nos elos trópicos analógicos que surgem contrastando-a com as narrativas da Guerra Colonial?

De facto, Antígona viola o nomos graptòs (a lei escrita) da polis ao pretender enterrar o corpo do irmão Polinice, que Creonte (por Polinice ter ousado lutar contra a polis) quer deixar insepulto naquele limiar de ninguém que é fora dos muros da cidade, domínio por excelência da alteridade. Se assim acontecesse, isto significaria apagar o nome e todos os traços do morto. Por isso, Antígona, em nome do nomos àgraphos (da lei antiga, mas não escrita) resolve transgredir a proibição, crime execrável em relação à comunidade que lhe custará a condenação a uma morte horrível - mas, significativamente, numa outra condição dual, trágica, ou seja, a de "enterrada viva”.

Como pode facilmente depreender-se dessa reconstrução sumária, há muitos elementos que remetem para a vertente feminina da literatura da Guerra Colonial. Antígona encena o conflito entre ontologia e política, privado e público, entre intimidade e polis, entre corpo e ordem. O conflito da "beleza terrível" do trágico chega a uma perfeição (Hegel) que não pode encontrar uma conciliação, uma resolução, o que torna o embate trágico um extraordinário correlativo do sublime. 
Mas é a relação corpo-política (Cavarero, 1995: 17-22) que se revela bem interessante. De facto, Antígona (embora pensemos nas autoras portuguesas) mostra a impossibilidade de construir um luto público, um céu da memória que simbolize uma perda colectivamente problemática (a memória do vencido): a condenação da polis, pelo contrário, é pelo apagamento de qualquer traço, portanto, pelo esquecimento sem resto ou, mas numa dimensão privada e fora de qualquer espaço público, pela conservação de restos que desencadeiam um inexaurível complexo melancólico. E também um outro elemento relevante é a posição de Antígona, limiar, fronteiriça, mas dentro duma relação trágica que, portanto, não se deixa traduzir, não admite mediações.

O que talvez diga mais respeito ao nosso tema, é uma questão por excelência trágica que Antígona aprofunda ainda mais, a questão da culpa. Encontramos de facto o conflito entre a culpa objectiva da tragédia, a amartia, e a responsabilidade da memória, o que torna a tragédia sofocliana uma obra absolutamente moderna, o que, por sua vez, explica o seu elevado número de "traduções" (George Steiner) até contrastantes entre si. O que interessa não é tanto interpretar o problema trágico na tragédia, mas ver como fora da rede da necessidade, da anakè trágica, e dentro do mundo da técnica isso se reflecte. Porque, como foi observado, e não somente em relação à vertente feminina, há na literatura da Guerra Colonial um tópico axial que é o da culpa (Teixeira, 1998: 103), o que poderia ser de algum modo compreensível, não pela redução ideológica da literatura da Guerra Colonial à "literatura de requiem", mas sim porque há uma culpa - trágica que caracteriza o processo pós-colonial de Portugal. E a tematização feminina da culpa, sub specie Antigonae poderíamos dizer, ganha uma evidência enorme. Pense-se na reminiscência do autoritarismo colonial da companhia, os ranchos folclóricos das culturas tradicionais, o elitismo da presença portuguesa. Em A Costa dos Murmúrios, a problematização do conflito trágico torna-se ainda mais evidente.

Não compreendo que pensamento cínico habitualmente me leva a estabelecer sobre o mundo, para sempre chegar à conclusão de que a culpa é um corpo celeste que existe além de nós e independentemente de nós. Não compreendo porque penso assim, e contemplando o que é nocivo, nunca culpe. [...] Agora porém, eu culpo (Jorge, 1988: 124; cf. também 156-157)

O que se nota no contraste entre corpo e política, que talvez seja o lugar (trágico) onde pode dar-se a conjugação, obviamente complexa, entre crise individual e crise colectiva do fim da colonização, é que a culpa objectiva (de ser português, de pertencer a um "destino" português, ultramarino, 
atlântico, de acordo com os mitos "escritos" da portugalidade que aliás ecoam irónicos em Percursos e em A Costa dos Murmúrios como em muita literatura da Guerra Colonial) é violada pela responsabilidade das autoras de dar testemunho ao que em si não se poderia testemunhar, uma responsabilidade bem mais ampla que só o trágico moderno admite. A responsabilidade - poderia observar-se - ocorre através de uma outra forma trágica que é o mecanismo do testemunho, que se articula a partir duma memória por sua vez trágica. No entanto, isso não impede que a culpa seja inexoravelmente exposta como fractura irrecuperável e os restos testemunhais possam instituir o elo entre memória e história, formando uma reflexão sobre a memória trágica do vencido massacrado que, como também ocorre na tragédia, se torna realmente objecto de meditação ético-política para a polis (Simone Weill). Este é o elemento que confere a essas poéticas trágicas o peso e o conteúdo de políticas trágicas sobre a desapropriação da experiência da guerra.

As descendentes portuguesas de Antígona talvez mostrem então justamente isso: as suas incoincidências trágicas em relação ao objecto do seu canto (a guerra) permitem-lhes "politizar o corpo" contra as políticas - nómicas mas impróprias - da polis com uma contra-memória trágica de restos e de rastos que devolve e anula, por murmúrios e bolhas, leve mas inexoravelmente, as revisões históricas racionalizadoras sobre a Guerra Colonial.

\section{Referências Bibliográficas}

Abraham Nicolas; Törok Maria (1993), La scorza e il nocciolo. Roma: Borla.

Agamben, Giorgio (1993), Stanze. La parola e il fantasma della cultura occidentale. Torino: Einaudi.

Agamben, Giorgio (1998), Quel che resta di Auschwitz. Torino: Bollati Boringhieri. Aristotele (2000), Poetica. Milano: Bompiani.

Cavarero, Adriana (1995), Corpo in figure. Filosofia e politica della corporeità. Milano: Feltrinelli.

Cavarero, Adriana (2003), A più voci. Filosofia dell'espressione vocale. Milano, Feltrinelli. Dahm, Johanna (2002), "Epitaffio”, in Nicolas Pethes; Jens Ruchatz (orgs.), Dizionario della memoria e del ricordo. Ed. it. a cura di A. Borsari. Milano: Bruno Mondadori. 166-167.

Foucault, Michel (1977), "Nietzsche, la genealogia, la storia", in Microfisica del potere. Interventi politici. Torino, Einaudi, 29-54.

Friedlander, Saul (1992), "Introduction", in Saul Friedlander (org.), Probing the Limits of Representation. Nazism and the "Final Solution". Cambridge/London: Harvard $\mathrm{UP}, 1-21$. 
Givone, Sergio (1996), "Prefazione”, in Peter Szondi, Saggio sul tragico. Trad. it. G. Garelli. Torino: Einaudi, VII-XXVI.

Jorge, Lídia (1988), A Costa dos Murmúrios. Lisboa: Dom Quixote.

Kaufman, Helena (1992), "Reclaiming the Margins of History", Luso-Brazilian Review, XXIX(1), 41-49.

Kierkegaard, Sören (1988), "Il riflesso del tragico antico nel tragico moderno", in Aut-Aut. Tr. it. de Cornelio Fabro. Firenze: Sansoni, 22-37.

Lacapra, Dominick (2001), Writing History, Writing Trauma. Baltimore: The John Hopkins UP.

Laranjeira, Pires (1991), “A Guerra Colonial na literatura de língua portuguesa”, JL, $\mathrm{X}(450), 12$.

Magalhães, Isabel Allegro de (1995), O sexo dos textos. Lisboa: Caminho.

Magalhães, Isabel Allegro de (1997), "Narrativas masculinas e femininas sobre a Guerra Colonial: dois exemplos de perspectivas marcadamente sexuadas", in Sentido que a vida faz. Estudos para Óscar Lopes. Porto: Campo das Letras, 285-296.

Magli, Patrizia (1985), "Il segno della differenza", in P. Magli (org.), Le donne e i segni. Scrittura, linguaggio, identità nel segno della differenza femminile. Ancona: Il Lavoro Editoriale, 11-22.

Maj, Barnaba (2001), "Tragedia greca e idea del tragico”, in Giorgio Penzo (org.), Filosofie nel tempo. Storia filosofica del pensiero occidentale e orientale. Roma: Spazio Tre, v. I, tomo II, 1265-1281.

Manzoni, Alessandro (1999), Lettera al Signor Chauvet sull'unità di tempo e di luogo nella tragedia. Ed. de Barnaba Maj. Firenze: Aletheia.

Medeiros, Paulo de (1999), "Memória infinita", Portuguese Literary \& Cultural Studies, 2, 61-77.

Medeiros, Paulo de (2000), "Hauntings: Memory, Narrative, and the Portuguese Colonial Wars", Cadernos de Literatura Comparada, I, 47-76.

Mesnard, Philippe; Kahan, Claudine (2001), Giorgio Agamben à l'epreuve d'Auschwitz. Paris: Kimé.

Ramos, Wanda (1981), Percursos - do Luachimo ao Luena. Lisboa: Presença.

Ribeiro, Margarida (2002), "As mulheres portuguesas e a Guerra Colonial”, in Rui de Azevedo Teixeira (org.), A guerra do Ultramar: realidade e ficção. Lisboa: Editorial Notícias, 211-220.

Santos, Maria Irene Ramalho de Sousa (1989), "Bondoso caos: A Costa dos Murmúrios de Lídia Jorge”, Colóquio/Letras, 107, 64-67.

Seligmann-Silva, Márcio (1998-99), "A história como trauma”, Pulsional, XI-XII, 108-127.

Seligmann-Silva, Márcio (1999), “A literatura do trauma”, Cult, São Paulo, 23, 40-47.

Teixeira, Rui de Azevedo (1998), A Guerra Colonial e o romance português. Agonia e catarse. Lisboa: Editorial Notícias. 
100 | Roberto Vecchi

Vecchi, Roberto (2001a), "Restos de experiências, rastos de memórias: algumas características da literatura da Guerra Colonial”, in Giuseppe Bellini; Donatella Ferro (orgs.), L'acqua era d'oro sotto iponti. Studi di Iberistica che gli amici offrono a Manuel Simões. Roma: Bulzoni.

Vecchi, Roberto (2001b), "Experiência e representação: dois paradigmas para um cânone literário da Guerra Colonial”, in Rui de Azevedo Teixeira (org.), A Guerra Colonial. Realidade e ficção. Lisboa: Notícias.

Weinrich, Harald (1999), Lete. Arte e critica dell'oblio. Bologna: Il Mulino.

Zizek, Slavoj (2002), "Lutto, malinconia e atto”, aut aut, 310-311, 39-63. 